\title{
Maximum extent of the Paleo-Kathmandu Lake in the late Pleistocene on the basis of piedmont gentle slope formation and lacustrine distribution in the Kathmandu basin, Nepal
}

\author{
Kiyoshi Saijoł* and Kazuo Kimurał \\ †Division of Social Studies Education, Miyagi University of Education, Sendai 980-0845, Japan \\ ‡Department of Social Science Study, Naruto University of Education, Naruto 772-8502, Japan \\ * To whom correspondence should be addressed. E-mail: saijo@staff.miyakyo-u.ac.jp
}

The Kathmandu basin is an intradeep located in the southern slope of the Nepal Himalaya. The basin, surrounded by ridges hangingaround $2000 \mathrm{~m}$ asl, extends between thealtitudes of 1200 and $1400 \mathrm{~m}$ asl and is filled by a thick sequence of lacustrine sediments deposited in the Paleo-Kathmandu lake during the Plioceneand Pleistocene. Several terracesurfaces, which occupy the basin floor, have been formed in response to the disappearance of the Paleo-Kathmandu lake, that was drained dueto southerlyerosion by the Bagmati river. This paper attempts to estimate theage and paleogeography in which the PaleoKathmandu lake was maximized and drained in terms of geomorphological investigation of the marginal area of thebasin. In particular, characteristics of piedmont gentleslopes, lacustrine distribution, and the relationship between them are examined.

The piedmont gentleslopeiswell developed at thejunction of thebasin floor and thesurrounding mountains. The piedmont gentle slope, dipping 7 to 15 degree towards the basin, shows a smooth surface with a slightly concave or almost linear vertical section. This slope coincides with alluvial and talus cones by Yoshida and Igarashi (1984), colluvial slope by Saijo (1991), and alluvial cone by Sakai et al. (2001). The piedmont gentle slope successively changesinto the Gokarna surface in thedirection of the basin in many places, and fades into narrow valleys in the back slopes. Surficial part (mostly less than $10 \mathrm{~m}$ deep) of the piedmont gentle slope is composed mainly of poorly sorted subrounded/subangular gravel or coarse sand with angular gravel. Thesesediments, tentatively called piedmont gentleslope deposit in this paper, are regarded as being of colluvial or fluvial origin. On the basis of their morphological characteristics and geomorphic settin integrated with the piedmont gentle slope deposit, it was determined that the piedmont gentle slope had been formed by debris supplied from thesurroundingmountain slopes.

Theorganic clayey sediments were found at both northern and southern margins of thebasin, and thepiedmont gentleslope deposit overlies or interfingers with them. It is estimated, therefore, that theseorganic clayey sediments are considered to be lacustrine deposited near the shoreline of the lake at the foothillsin arisingtrend of lakelevel. Such depositsarerecognized up to an altitude of between 1420 and 1440 m asl Several radiocarbon dates obtained from these lacustrine indicate that the uppermost part of them was deposited between 37100 and 29200 yr B.P. We can therefore conclude that themaximum level of the Paleo-Kathmandu lakereached at least 1420 to $1440 \mathrm{~m}$ asl and the lake occupied almost all of the basin around $30000 \mathrm{yr}$ B.P. Judging from the relationship between the piedmont gentle slope deposit and the lacustrine, the debris derived from the surrounding mountains was frequently transported and flowed into thelake.

These estimates suggest a possibility that the PaleoKathmandu lakewasdrained not by theBagmati river butanother river. However, the cols on the divide of the surrounding mountains occur at the altitudes between 1465 and $1500 \mathrm{~m}$ asl. If weignoretectonic movement, it is apparent that thealtitudes of the cols were higher than the estimated maximum level of the Paleo-Kathmandu lake. In addition, the red weathered bedrocks are observed in topsoil of the cols on the divide. This also suggests that those cols were not covered by the lake water and overflow from the cols did not occur. It is estimated that the drainage of the lakeby theBagmati river occurred just after 30000 yr BP and the lake has been gradually reduced. The Gokarna surface emerged in conjunction with the drainage of the lake. Supply of the debrisfrom thesurroundingmountainscontinued even after therecession of thelakeand resulted in the piedmont gentleslopeformation.

\section{References}

YoshidaM and Y Igarashi. 1984. Neogeneto Quaternarylacustrinesediments in the Kathmandu Valley, Nepal. J Nepal Geol Soc 4: 73-100

Saijo K. 1991. Slope evolution since latest Pleistocene time on the north slope of Chandragiri, Kathmandu valley in the middle mountains of Nepal. ScienceReports of theTohoku University, 7th Series (Geography) 41: $23-40$

Sakai T, AP Gajurel, H Tabata and BN Upreti. 2001. Small amplitude lake level fluctuations recorded in aggrading delta deposits of the lower parts of the Thimi and Gokarna Formations (upper Pleistocene), Kathmandu Valley.J Nepal Geol Soc 25: 43-51 